\title{
Semantic Condensations in French and Russian Proverbs Based on the Thematic Group Family
}

\author{
Natalia Yu. Nelyubova ${ }^{\mathbb{D}}$, Natalia M. Dugalich ${ }^{1 \mathbb{D}} \square$, Victor I. Ershov $^{2} \mathbb{D}$ \\ ${ }^{1}$ RUDN University, \\ 6, Miklukho-Maklay srt., Moscow, Russian Federation, 117198 \\ ${ }^{2}$ MGIMO University, \\ 3, Novo-Sportivnaya, Odintsovo, Moscow region, Russia Federation, 143005
}

$\checkmark$ dugalich_nm@rudn.ru

\begin{abstract}
The article is devoted to the study of semantic condensations in French and Russian proverbs from the point of view of family values perception by native speakers of French and Russian. The analysis was carried out based on a study of a card index of proverbs extracted from paremiographic sources that offer a presentation of the material on a thematic basis and contain headings and subheadings related to family and family relations. In order to achieve greater objectivity of the results, the authors carried out a selection and counting of the number of identical proverbial units of the studied thematic group both in French (114 units) and Russian (270 units) paremiological dictionaries. A quantitative and semantic analysis of the key lexemes associated with family presented in the titles of headings, subheadings and proverbs of the card index allowed identify semantic condensations, which most clearly reflect behavioural priorities and peculiaritites of values comprehension. Proverbial semantic condensations are understood as the main meanings and moral and ethical formulations, containing in a condensed form the meaning of a proverb and excluding its figurative component, which may differ in various languages. A comparative analysis made it possible to identify both universal and specific components in the considered French and Russian proverbial condensations, as well as values and anti-values adjacent to the family, which enables us to characterize their perception and functioning in the system of value coordinates of the studied ethnic groups. The presence of significant similarities is explained by the universality of family values and their understanding. Differences mainly lie in the fact that in the French material there is a more individualistic and pragmatic-everyday orientation, while in the Russian material there is a tendency towards the collective (family) and an emotional-sensory orientation. Russian proverbs are distinguished by a greater degree of concentration of thematic key lexemes. The differences in semantic condensations, the value perception of the family, and their representation using units of different linguistic levels, the functioning of which is explained by a combination of typological features of the compared languages, once again demonstrated the connection between the latter, the uniqueness of the world perception and the way of thinking of individual ethnic groups.
\end{abstract}

Key words: French proverbs, Russian proverbs, paremiographic sources, family values, proverbial semantic condensation

(C) Nelyubova N.Yu., Dugalich N.M., Ershov V.I., 2021

This work is licensed under a Creative Commons Attribution 4.0 International License https://creativecommons.org/licenses/by/4.0/ 
Financing. Acknowledgement

This publication was supported by the RUDN University Strategic Academic Leadership Program (Russian Federation)

\title{
Article history:
}

Received: 01.08.2021

Accepted: 15.09 .2021

\section{For citation:}

Nelyubova, N.Yu., Dugalich, N.M. \& Ershov, V.I. (2021). Semantic Condensations in French and Russian Proverbs Based on the Thematic Group Family. RUDN Journal of Language Studies, Semiotics and Semantics, 12(4), 1051-1074. doi: 10.22363/2313-2299-2021-12-4-1051-1074

УДК [811.133.1+811.161.1]'373:398.91

\section{Семантические конденсаты во французских и русских пословицах на примере тематической группы «семья»}

\author{
Н.Ю. Нелюбова ${ }^{1} \mathbb{D}$, Н.М. Дугалич1 ${ }^{1} \square$, В.И. Ершов ${ }^{2} \mathbb{D}$ \\ ${ }^{1}$ Российский университет дружбы народов, \\ 117198, Российская Федерация, Москва, ул. Миклухо-Маклая, 6 \\ ${ }^{2}$ Одинцовский филиал МГИМО, \\ 143005, Российская Федерация, Московская область, Одинцово, ул. Ново-Спортивная, 3 \\ $\checkmark$ dugalich_nm@rudn.ru
}

\begin{abstract}
Аннотация. Статья посвящена исследованию семантических конденсатов во французских и русских пословицах с точки зрения восприятия семейных ценностей носителями французского и русского языков. Анализ проведен на основе изучения картотеки пословиц, извлеченных из паремиографических источников, предлагающих представление материала по тематическому принципу и содержащих рубрики и подрубрики, связанные с темой семьи и семейных отношений. С целью достижения большей объективности результатов осуществлена выборка и подсчет количества одинаковых пословичных единиц изучаемой тематической группы в двух французских (114 единиц) и двух русских (270 единиц) паремиологических словарей. Количественный и семантический анализ ключевых лексем, связанных с семьей, представленных в названиях рубрик, подрубрик и пословицах полученной картотеки, позволил выявить семантические конденсаты, в которых наиболее четко отражаются поведенческие приоритеты и особенности осмысления ценностей. Под пословичными семантическими конденсатами понимаются основные смыслы и морально-нравственные формулировки, содержащие в сжатом виде смысл пословицы и исключающие ее образный компонент, который в разных языках может различаться. Сопоставительный анализ позволил выявить как универсальные, так и специфические компоненты в рассмотренных французских и русских пословичных конденсатах, а также сопредельные семье ценности и антиценности, позволяющие охарактеризовать ее восприятие и функционирование в системе ценностных координат изучаемых этносов. Наличие значительного сходства объясняется универсальностью семейных ценностей и их понимания. Различия в основном заключаются в том, что во французском материале наблюдается более индивидуалистская и прагматически-бытовая направленность, а в русском - ориентация на коллектив (семью) и эмоционально-чувственная направленность. Русские пословицы отличаются большей степенью концентрации тематических
\end{abstract}


ключевых лексем. Различия семантических конденсатов, как и ценностного восприятия семьи, и их репрезентация с помощью единиц различных языковых уровней, особенности функционирования которых объясняются сочетанием типологических особенностей сопоставляемых языков, еще раз продемонстрировали связь последних с уникальностью мировосприятия и мышления отдельных этносов.

Ключевые слова: французские пословицы, русские пословицы, паремиографические источники, семейные ценности, пословичный семантический конденсат

\section{Финансирование. Благодарности}

Публикация выполнена при поддержке Программы стратегического академического лидерства РУДН (Российская Федерация)

\section{История статьи:}

Дата поступления: 01.08.2021

Дата приема в печать: 15.09.2021

\section{Для цитирования:}

Nelyubova N.Yu., Dugalich N.M., Ershov V.I. Semantic Condensations in French and Russian Proverbs Based on the Thematic Group Family // Вестник Российского университета дружбы народов. Серия: Теория языка. Семиотика. Семантика. 2021. Т. 12. № 4. С. 1051-1074. doi: 10.22363/2313-2299-2021-12-4-1051-1074

\section{Introduction}

Family is one of the generally recognized basic cultural values. The scope of the meaning of the lexeme family has been changing depending on the era, and the phenomenon itself has acquired new characteristics due to the specifics of the development and functioning of society. In different cultures, there is a different perception of marriage and family and kinship relations, which is reflected in different ways in the language system. Thus, since "the family is a universal human value, reflecting the specifics of national culture, depending on historical, geographical and political conditions; it acts as a pivotal element of the moral principles of society" [1. P. 29], it is relevant to determine its perception by representatives of various types of cultures.

Despite the presence in modern society of various forms of family existence, the perception of it as a universal, timeless value is confirmed by sociological research. According to 2018 data, for $86 \%$ of French people, family is very important, ahead of other values: work (62\%), friends and acquaintances $(53 \%)$, leisure $(34 \%)$, religion $(15 \%)$ and politics $(10 \%)$. At the same time, $63 \%$ find traditional marriage important [2. P. 151, 153]. Russians also consider the family to be one of the most important traditional values (58\% of the respondents). Health is mentioned in second place, followed by money, work, home, housing, etc. [3].

The values of the ethnos are directly reflected in the language, because "language and its communicative realization - speech in distinct unity and existence - provide the categorization of reality and storage of the information and knowledge received" [4. P. 597]. Mental constants of the people are often formulated in the form of paroemias, which "act as forwarders of traditions, 
mentality, national character, social experience" [5. P. 313], illustrating "spiritual, moral and utilitarian values". Despite the difference in figurative concretization, many proverbs express "common human priorities of behaviour" [6 . P. 29]. In addition, "in the context of paroemias, basic national values are rethought in accordance with national and cultural experience, demonstrating an amazing mental "flexibility" and polyphony in assessing the most significant for a person values" [7. P. 266-267]. Thus, since the concentrated expression of values are paroemias in general and proverbs, we have chosen them as the basic linguistic unit for the comparative analysis.

In this article, we proceed from the idea that behavioural priorities and features of value comprehension are reflected in proverbial semantic condensations. "The proverbial fund of various languages, regardless of their genetic classification, distinguishes a semantic condensation (E.I. Seliverstova), semantic dominants (O.V. Lomakina, V.M. Mokienko), or an axiologeme (L.K. Bayramova) semantics, uniting paroemias of one or several languages, that allows expressing the main meanings and moral and ethical attitudes" [8. P. 172-173].

The share of the national component in the proverbial fund becomes much smaller if we consider the features common to units of this genre in comparative studies of the material of different languages. Having mentally excluded from the proverb "metaphor, lexical redundancy, rhythm, rhyme, etc., then its essence can appear in the form of two or three components, expressing the meaning of paroemia in a condensed form. It is difficult to call it a 'proverb' due to the lack of the necessary proverbial markers, but we can call it a proverbial condensation, a proverbial idea" [9. P. 59]. E.V. Ivanova uses the concepts "cognition" and "cognitive model". E. Kokare speaks about proverbial types: a type combines synonymous proverbs that have the same ideological content, which can be expressed by different images and linguistic means [Cit. by: 10. P. 88-89].

This study uses the term "proverbial semantic condensation", which, in our understanding, expresses the main meanings and moral and ethical formulations, containing in a condensed form the meaning of a proverb and excluding its figurative component, that may differ in various languages.

The purpose of this article is to identify and compare the main semantic condensations of French and Russian proverbs of the thematic group family, obtained from dictionaries, in an axiological perspective.

The research methodology included the following stages:

- the choice of two French and two Russian dictionaries of proverbs, offering the presentation of the material on a thematic basis, since the names of thematic associations of proverbs reflect the main vital conceptual spheres, and, consequently, the value orientations of the ethnos;

- identification and counting of the number of identical proverbial units of the studied thematic group in both French and Russian paremiographic sources with a view to achieving greater objectivity of the results; 
- quantitative and semantic analysis of key lexemes associated with the family and presented in the titles of headings, subheadings and proverbs of the card index of French and Russian material in order to identify semantic condensations;

- comparative characteristic of the universal and specific components in the obtained French and Russian proverbial condensations from the point of view of reflecting value orientations in them;

- identification of values adjacent to the family so as to characterize its functioning in the system of value orientations of the studied ethnic groups.

When working with paremiological material, we proceed from the idea that the vocabulary direction is one of the ways to reconstruct the paremiological picture of the world [11. P. 127]. The examples presented in the article are selected from our card index, which includes 114 French and 270 Russian proverbs about family. The translation of French proverbs and Russian equivalents are proposed by the authors and are partially taken from Internet sources [12].

\section{Analysis of French proverbs}

The representation of the thematic group family is reflected in the dictionaries of French and Russian proverbs and is manifested primarily in the names of the headings, which make it possible to identify the key lexemes that characterize the studied group. The French dictionary of proverbs and sayings [13] does not call it directly. The relevant topics are reflected in the headings: La vie domestique / home life (116 units) and Les objets usuels / household items (83 units). Earlier we gave a detailed description of the headings and a commentary on the semantics of French proverbs about the family based on this dictionary [14]. The lexeme family occurs once in the names of subheadings, other names are based on the concepts traditionally associated with and revealing it: la vie domestique / home life (53 proverbs), which lists 21 general proverbs and highlights smaller subheadings: le ménage, l'épouse / couple, spouse (20 units) and le mariage / marriage (12). Subheading la femme / wife / woman includes 28 units; les enfants, les relations de famille / children and family relations - 27, l'habitat / dwelling - 8 .

To obtain more objective data on the representation of the theme family and semantic condensations, we have compiled a card index of the same proverbs given in two dictionaries $[13 ; 15]$. The electronic dictionary of French proverbs [15] has a subheading Famille / family (36 units, 14 of which are proverbs from France and 1 from Martinique) in the rubric Relations humaines / human relations.

The electronic dictionary was used to make a search for all the proverbs of the above headings of the printed dictionary. In total, 114 common units were identified, placed in the electronic dictionary in different headings, which is understandable: the theme and value of the family is one of the central ones in the consciousness of each ethnic group and is closely related to various areas of life.

Let us consider the key lexemes associated with the family, and the frequency of their use in the proverbs of the card index. The results are presented in Table 1 in descending order of frequency. 
Table 1 / Таблица 1

\section{Key lexemes of French proverbs of the thematic group family and the frequency of their use}

Ключевые лексемы французских пословиц тематической группы «семья» и частотность их употребления

\begin{tabular}{|c|c|c|c|}
\hline Key lexeme & Examples & $\begin{array}{l}\text { Number } \\
\text { of uses }\end{array}$ & $\begin{array}{l}\text { Percentage } \\
\text { of uses per } \\
\text { total number } \\
\text { of proverbs }\end{array}$ \\
\hline $\begin{array}{l}\text { Femme / } \\
\text { wife, woman }\end{array}$ & $\begin{array}{l}\text { 1. Des femmes et des chevaux il n'y en a point sans } \\
\text { défaut / There are no flaws in women and horses } \\
\text { 2. L'homme est pour le purgatoire, la femme pour } \\
\text { l'enfer (Martinique) / Purgatory is for men, hell is for } \\
\text { women } \\
\text { 3. Qui femme a, noise a / Got a wife, forget the silence }\end{array}$ & 15 & 13,2 \\
\hline $\begin{array}{l}\text { Maison / } \\
\text { house }\end{array}$ & $\begin{array}{l}\text { 4. Maison faite et femme à faire / Take a ready house, } \\
\text { and a pliable wife }\end{array}$ & 7 & 6,1 \\
\hline $\begin{array}{l}\text { Enfant(s) / } \\
\text { child, } \\
\text { children }\end{array}$ & $\begin{array}{l}\text { 5. Enfant haï est toujours triste / A hated child is always } \\
\text { sad } \\
\text { 6. Celui qui n'a qu'un enfant n'en a aucun / У кого } \\
\text { только один ребенок, детей нет } \\
\text { Who has only one child has no children at all } \\
\end{array}$ & 7 & 6,1 \\
\hline $\begin{array}{l}\text { Fille / } \\
\text { girl, daughter }\end{array}$ & $\begin{array}{l}\text { 7. Jolie fille porte sa dot au front / A beautiful girl wears } \\
\text { a dowry on her forehead } \\
\text { 8. La plus belle fille du monde ne peut donner que ce } \\
\text { qu'elle a / The most beautiful girl in the world can't give } \\
\text { more than she has }\end{array}$ & 6 & 5,3 \\
\hline $\begin{array}{l}\text { Homme / } \\
\text { man, human }\end{array}$ & $\begin{array}{l}\text { 9. Il faut aux filles des hommes et des murailles / } \\
\text { 10. Girls need either a husband or monastery walls } \\
\text { 11. Beauté de femme n'enrichit l'homme / Feminine } \\
\text { beauty doesn't make a man richer }\end{array}$ & 6 & 5,3 \\
\hline $\begin{array}{l}\text { Père / } \\
\text { father }\end{array}$ & $\begin{array}{l}\text { 12. Un père peut nourrir cent enfants mais cent enfants } \\
\text { ne nourriraient pas un père / One father can feed one } \\
\text { hundred children, but one hundred children cannot } \\
\text { feed one father }\end{array}$ & 4 & 3,5 \\
\hline $\begin{array}{l}\text { Mère, } \\
\text { maman / } \\
\text { mother }\end{array}$ & $\begin{array}{l}\text { 13. Folle mère pour enfant / Mother is crazy about her } \\
\text { child } \\
\text { 14. Une maman n'est un bon bol à couvercle } \\
\text { (Martinique) / Mother is a lovely bowl with a lid } \\
\text { (Martinique) }\end{array}$ & 3 & 2,6 \\
\hline $\begin{array}{l}\text { Fils / } \\
\text { son }\end{array}$ & $\begin{array}{l}\text { 15. Tel père, tel fils / The son is alike his father } \\
\text { 16. A père avare, fils prodigue / A stingy father has } \\
\text { a waster son }\end{array}$ & 2 & 1,8 \\
\hline $\begin{array}{l}\text { Famille / } \\
\text { family }\end{array}$ & $\begin{array}{l}\text { 17. Il faut laver son linge sale en famille Don't wash } \\
\text { dirty linen in public }\end{array}$ & 2 & 1,8 \\
\hline $\begin{array}{l}\text { Frère / } \\
\text { brother }\end{array}$ & 18. Tantôt frère, tantôt larron / Now brother, then a thief & 1 & 0,9 \\
\hline $\begin{array}{l}\text { Gendre / } \\
\text { son-in-law }\end{array}$ & $\begin{array}{l}\text { 19. Amitié de gendre, soleil d'hiver } \\
\text { A son-in-law's friendship of is like the winter sun }\end{array}$ & 1 & 0,9 \\
\hline $\begin{array}{l}\text { Belle-mère / } \\
\text { mother-in- } \\
\text { law }\end{array}$ & $\begin{array}{l}\text { 20. Quand vous êtes bien habillé, vous ne rencontrez } \\
\text { pas votre belle-mère (Guadeloupe) / When you are well } \\
\text { dressed, you do not meet your mother-in-law } \\
\text { (Guadeloupe) }\end{array}$ & 1 & 0,9 \\
\hline $\begin{array}{l}\text { Voisin / } \\
\text { neighbour }\end{array}$ & $\begin{array}{l}\text { 21. Qui a bon voisin, a bon matin / } \\
\text { Whoever has a good neighbour has a good morning }\end{array}$ & 1 & 0,9 \\
\hline
\end{tabular}


The analysis showed the highest frequency of the lexeme femme /woman, wife, and in 9 cases out of 15 it is used precisely in the meaning woman. We find a lexeme fille /daughter, girl in 6 proverbs. A detailed commentary on the semantics of proverbs about a woman and a wife was given by us earlier [14. P. 52; 16]. The revealed features are explained by the fact that each language carries traces of patriarchy, which implies gender asymmetry in the assessment of women in paremiology: traditionally, a woman is assessed by a man [17. P. 89] as an anonymous author of proverbs, and the assessment is mainly critical, cynical, bordering on misogyny, which is repeatedly emphasized in the comments by the authors of the French dictionary of proverbs and sayings [13].

Our material revealed the following semantic condensations of proverbs about a woman and a wife: tips on how to choose the right wife:

21. D'une bonne vigne prenez le plant; d'une bonne mère prenez la fille / Take a vine from a good vineyard, and a daughter from a good mother - in this proverb there is a widespread and often positive metaphorical image of a vineyard, symbolizing a given by nature value that needs to be protected [13. P. 33], especially in a country where winemaking has been a traditional activity since ancient times;

22. Ne prends jamais femme chez un cafetier, ni une vache chez un meunier / Do not take a wife from the owner of a café, and a cow from a miller - both will cost a lot;

The need for the wife's obeyance to her husband as a factor of a happy family life is expressed metaphorically with the help of zoonyms:

23. Le ménage va mal quand la poule chante plus haut que le coq / Things are bad in a family where a hen sings louder than a rooster - the image of a hen is used in proverbs to denote the subordinate role of women in the family [13. P. 52] in relation to a man, represented in the form of a rooster;

A critical and cynical attitude towards a woman can be expressed directly (using linguistic units of negative evaluative semantics), simultaneously with a metaphorical parallel or only metaphorically. Various ways of representation are shown in examples $1-3,21-23$, as well as:

24. Femme et vin ont leur venin / The woman and the wine have their own poison - this proverb, like example 21 , this one once again confirms that the theme 'wine' occupies a special place in French paroemias, and the metaphorical image of wine, along with vineyard, is used to characterize various life situations [18. P. 979];

25. Femme sotte se connaît à la toque / A stupid woman is recognized by her hat;

26. Fumée, pluie et femme sans raison chassent l'homme de sa maison / Marriage makes or mars a man.

An equally cynical, but a softer attitude is observed towards daughters and girls (examples 7, 8). However, the idea of a necessary control which can be given either by a man or life in a monastery is emphasized (example 9).

A man (lexeme homme / man, a person is found in 6 proverbs) acts, as noted above, in the role of a controller, a judge, he is unhappy that he can marry 
unsuccessfully (see example 40 below), blaming for an unhappy marriage an unreasonable woman and natural phenomena (example 26).

The lexeme maison / house ( 7 units) has a high degree of frequency. These units are united by the semantics 'shelter, asylum', which allows the following semantic condensation to be derived: The house must be taken care of and full of warmth:

27. Gardez votre maison, elle vous gardera / Take care of your home and it will take care of you;

28. Maison sans flamme, corps sans âme / A house without fire, a body without a soul and prosperity:

29. Farine fraîche et pain chaud font la ruine de la maison (Suisse) Fresh flour and hot bread are ruinous because they are eaten very quickly (Suiss) - reflects the value of frugality.

Besides, in the meaning 'maison / house' we sometimes find neutral logis / dwelling: and $\mathrm{nid} /$ nest - a metaphorical symbol of a house:

30. Suivant l'oiseau, le nid; suivant l'homme, le logis / The bird leads to the nest, the person to the house.

The presence of lexemes denoting some parts of the house or furniture is illustrative: for example, porte / door (3 uses) functions as a symbol of entering and exiting a house, its boundaries:

31. Que chacun balaie devant sa porte et les rues seront nettes / Let everyone sweep in front of his door, and the streets will be clean;

32. Il faut qu'une porte soit ouverte ou fermée / It is necessary that the door was either open or closed;

33. Le dernier venu ferme la porte / The last person to enter closes the door.

We should note the importance of the boundaries of the home and personal boundaries of representatives of the French linguistic culture, which is traditionally related to the culture of the individualist type, and which has received an obvious reflection in the proverbial fund as a mirror of the experience of the studied ethnos. Moreover, as one of the leading trends in modern French society, researchers note individualization, a high degree of autonomy, including in the family [2;19].

There is a single use of the following lexemes:

- cuisine / kitchen - as a central place in the house where the family gathers:

34. Petite cuisine, grosse famille (Québec) / The kitchen is small — the family is big (Quebec);

- grenier / attic:

35. Quand la maison est trop haute, il n'a rien au grenier / When the house is tall, the attic is empty - this metaphor characterizes tall people whose heads are empty.

- chaise / chair as a necessary piece of furniture, a symbol of the stable presence of someone or something in the house:

36. Quand le malheur entre dans une maison, faut lui donner une chaise (Québec) / When misfortune comes to the house, give it a chair - it will settle here for a long time (Quebec). 
We also note the presence in our material of the following lexemes associated with the family (few cases of use):

- fiançailles / engagement:

37. Fiançailles vont en selle et repentailles en croupe / Engagement in the saddle, follows the remorse - this proverb reflects the need to weigh your decisions on the example of such serious steps as engagement;

- épouser, se marier / get married:

38. Qui épouse la femme épouse les dettes / Whoever marries a woman marries her debts;

- marié / married:

39. Il y a plus de mariés que de contents / More married than happy;

40. Un homme mal marié, il vaudrait mieux qu'il fût noyé / It is better to drown than marry unsuccessfully - in the previous three proverbs, we observe the theme of an unhappy marriage and a negative assessment of a woman: this refers to the unhappiness of married men, not married women, thus emphasizing the responsibility of the woman for family happiness and minimizing the responsibility of the man, who is obviously considered the master of the house:

41. Charbonnier est maittre chez soi / The coal miner is the boss in his house this proverb means that everyone is the boss in his house, and not a single proverb from our material directly mentions the mistress of the house.

Not only family members play a role, but also neighbours: example 20 expresses the importance of good neighbourly relations.

Only the closest relatives are mentioned: father, mother, son, daughter, brother, son-in-law, mother-in-law. The last three degrees of relationship are mentioned only once (examples 17-19). Analysis of this layer made it possible to identify the following semantic condensations, in addition to the already mentioned possible unhappiness in marriage: the ingratitude of children (example 11), the power of maternal love, sometimes bordering on insanity (example 12), the mother's desire to hide the shortcomings of her child (example 13), the similarity of the parents and children, on the one hand, and their difference, on the other (examples 14, 15). Despite the peculiarities of the specified semantics, the material proves the importance of having a child in the family and better than more than one (example 6): in 15 proverbs there are lexemes enfant / child, fille / daughter, fils / son, parenting is also very important: 7 proverbs about fathers and mothers.

It is interesting to note that, according to a sociological survey, the place of children in a modern French family is still one of the most important, ranking second after fidelity in relationships, although this indicator has decreased compared to 2008 data. Most of the population considers having a child more of a factor in a successful family than a duty to society, although opinion may depend on a number of social factors: age, family experience, religious beliefs, etc. In any case, the question of whether to have children or not and when is more and more related to personal choice [2. P. 169, 171].

Family ties are reflected through the connections of the above concepts by mentioning several key lexemes within one unit, and often none of them prevails, 
but all can be considered as equivalent: see examples $2,4,10-12,14,15,17,21$, $23,26,30,34-36,38$. The analysis made it possible to identify contiguous values and value dyads: happiness - unhappiness (examples 5, 23, 26, 36, 37, 39, 40) love - hatred $(5,12,13)$, wealth - poverty $(22,29,38)$; intellect - stupidity, notably, only feminine $(25,26)$; food, gastronomy $(24,29)$; beauty $(7,8)$; faith, religion (2); friendship - enmity (18), life — death (40).

We consider the second rubric Les objets usuels / household items due to the obvious connection between everyday life and family life. The presence of a large number of proverbs with key lexemes-designations of household utensils in it serves as the names of subheadings and testify to the importance in the minds of French speakers of the practical, everyday side of family life. These units once again confirm the idea that the verbalization of folk-cultural historical traditions "is based on images that use the realities of traditional life and fixes the national character of paroemias" [20. P. 318]. These designations underlie the metaphorical image used to describe a variety of life situations: assiette plate, écuelle / bowl, chaudron / boiler, plat / dish, marmite / pot, saucepan, poêle / frying pan, bouteille / bottle, tonneau / barrel, pot / pot, couvercle / lid, verre / glass, coupe / cup, flute / wineglass, ciseaux / scissors, couteau / knife, torchon / rag, serviette / towel, mortier / pounder, sac / bag, boîte / box, chandelle / candle, lampe / lamp, clé / key, clou / nail, miroir / mirror.

Some of these lexemes serve as metaphorical designations for relatives, allowing us to also identify a number of semantic condensations:

42. Il n'y a si méchant pot qui ne trouve son couvercle / There is no pot that is so bad for which there is no lid. In this proverb, as in the next one, we are talking about a woman who is looking for a husband;

43. Chaque chaudron trouve son couvercle (Québec) / Each pot finds its own lid (Quebec);

44. Petit chaudron, grandes oreilles / The bowler hat is small, but the ears are large - this case implies the image of a child, who attentively listens to everything that is said in the house.

With regard to the material studied, it should be noted that there are not only proper French units, which make up the absolute majority, but also proverbs of French-speaking countries. Their detailed analysis is presented in our previous works $[16 ; 21 ; 22]$. Of the 114 units of our card index, the analysis of which is presented in this article, 11 of them were identified (see examples 2, 13, 19, 29, 34, 36, 43): 4 proverbs of Martinique, 3 - Guadeloupe, 3 - Quebec and one Swiss.

\section{Analysis of Russian proverbs}

While studying the material of Russian proverbs, we also combined the data of two dictionaries $[23 ; 24]$. The dictionary by V.M. Mokienko and T.G. Nikitina [24] heading Брак и семья / Marriage and family (1236 items) includes subheadings Женатый - холостой / Married — single (26 units), Жених невеста / The groom and the bride (78), Свадьба / Wedding (20), Семейная жсизнь / Family life (83), Мужс-жена / Husband and wife (346), Родители - 
детu / Parents and children (432), Браm - cecmpa / Brother and sister (33), Дpyгие родственники / Other relatives (190), Вдовство - одиночество / Widowhood and loneliness (28). The indicated names, as in the French material, demonstrate the key lexemes representing the theme of the family, which also received partial reflection in the heading Мужчина и женциина / Man and woman (347 proverbs), including a number of subheadings: Молодость и старость: Youth and old age, Юноша — девуика / Young man — young girl (92 units), Старик - старуха / Old man — old woman (55); Ум, смекалка / Mind, savvy (27); Характер, поведение, привычки / Character, behaviour, habits (117); Труд / Work (32); Социальный статус, положение в семье / Social status, position in the family (24).

The presence of the proverbs of these headings, in addition, was verified according to the dictionary by V.I. Zimin [23], which offers numerous subheadings within the heading Свои люди (жених и невеста, сватовство, свадьба, цепи Гименея, о супружеской верности и ревности, семья, родня) / Our реорle (bride and groom, matchmaking, wedding, chains of Hymen, about marital fidelity and jealousy, family, relatives), numbering 465 units, and a separate heading Дети / Children - 279 (total - 744 units). The search was based on the proverbs from the dictionary by V.M. Mokienko and T.G. Nikitina, since in the dictionary by V.I. Zimin we collected not only proverbial, but also broader phraseological material. In total, 237 common units were found (source material proverbs of the heading Брак и семья / Marriage and family of the dictionary by V.M. Mokienko, T.G. Nikitina) 33 common units (source material - proverbs of the heading Мужчина и женцина / Man and woman of the same dictionary).

The results of the analysis of the frequency of key lexemes use in our material and the percentage of their use for the total number of proverbs are shown in Table 2.

Table 2 / Таблица 2

\section{Key lexemes of Russian proverbs of the thematic group family and the frequency of their use \\ Ключевые лексемы русских пословиц тематической группы «семья» и частотность их употребления}

\begin{tabular}{|c|c|c|c|}
\hline Key lexeme & Examples & $\begin{array}{c}\text { Number } \\
\text { of uses }\end{array}$ & $\begin{array}{c}\text { Percentage } \\
\text { of uses }\end{array}$ \\
\hline $\begin{array}{l}\text { Жена / } \\
\text { wife }\end{array}$ & $\begin{array}{l}\text { 45. Добрая жена, да жирные щи - другого добра } \\
\text { не ищи / A kind wife, means fat cabbage soup - } \\
\text { don't look for any other good } \\
\text { 46. В чужую жену черт ложку меда кладет / } \\
\text { The devil puts a spoonful of honey into someone } \\
\text { else's wife } \\
\text { 47. Добрая жена дом сбережет, а плохая - } \\
\text { рукавом разнесет / A good wife will save the house, } \\
\text { and a bad wife will smash it with her sleeve } \\
\text { 48. Худо тому, у кого жена хозяйкой в дому / } \\
\text { It's bad for someone who has a wife as a mistress } \\
\text { in the house } \\
\text { 49. Убоится жена мужа, да не дюже / } \\
\text { The husband's wife will be afraid, but not hefty }\end{array}$ & 53 & 20 \\
\hline
\end{tabular}


Continuation of the table 2 / Продолжение табл. 2

\begin{tabular}{|c|c|c|c|}
\hline Key lexeme & Examples & $\begin{array}{c}\text { Number } \\
\text { of uses }\end{array}$ & $\begin{array}{c}\text { Percentage } \\
\text { of uses }\end{array}$ \\
\hline $\begin{array}{l}\text { Ребенок, дитя, } \\
\text { дети / child, } \\
\text { children }\end{array}$ & $\begin{array}{l}\text { 50. Маленькие детки - маленькие бедки, } \\
\text { a большие выросли - большие бедки / Little kids } \\
\text { are little troubles, and big kids are big troubles } \\
\text { 51. Дети - цветы жизни / Children are flowers } \\
\text { of life } \\
\text { 52. Каков батюшка, таковы и детки / What is the } \\
\text { father, so are the children }\end{array}$ & 44 & 16,3 \\
\hline $\begin{array}{l}\text { Муж / } \\
\text { husband }\end{array}$ & $\begin{array}{l}\text { 53. У умного мужа и дура умней выглядит / } \\
\text { A smart husband and a foolish wife looks smarter } \\
\text { 54. За хорошим мужем и свинка господинка / } \\
\text { A good husband and a piggy is a queen } \\
\text { 55. Муж не уж, а кровь сосет / Husband isn't a } \\
\text { grass snake but stings }\end{array}$ & 32 & 11,9 \\
\hline $\begin{array}{l}\text { Мать, матка, } \\
\text { материнский / } \\
\text { mother, } \\
\text { maternal }\end{array}$ & $\begin{array}{l}\text { 56. При матери добро, при солнышке тепло / } \\
\text { It's good with mother, warm with the sun } \\
\text { 57. У кого есть матка, так и головушка гладка / } \\
\text { Whoever has a mother, so the head is cherished } \\
\text { 58. Материнская молитва со дна моря достанет / } \\
\text { A mother's prayer will reach from the bottom of the } \\
\text { sea }\end{array}$ & 30 & 11,1 \\
\hline $\begin{array}{l}\text { Сын / } \\
\text { son }\end{array}$ & $\begin{array}{l}\text { 59. Не хвались отцом, ахвались сыном-молодцом / } \\
\text { Do not boast of a father, but boast of a good son } \\
60 \text {. Один сын - не сын, а два - не кормильцы / } \\
\text { One son is not a son, and two are not breadwinners } \\
61 . \text { Сын за отца не отвечает / The son is not } \\
\text { responsible for the father }\end{array}$ & 24 & 8,9 \\
\hline $\begin{array}{l}\text { Отец, батька / } \\
\text { father, daddy }\end{array}$ & $\begin{array}{l}\text { 62. Отец гряды копал, а сын в воеводы попал / } \\
\text { The father dug the ridge, and the son became the } \\
\text { governor } \\
\text { 63. Отец рыбак, а дети в воду смотрят / The father } \\
\text { is a fisherman, and the children look into the water } \\
\text { 64. Отец сыну своего ума не даст / Father will not } \\
\text { give his son his mind }\end{array}$ & 22 & 8,2 \\
\hline $\begin{array}{l}\text { Любовь / } \\
\text { love }\end{array}$ & $\begin{array}{l}\text { 65. Любовь холостого как вешний лед / A single's } \\
\text { love is like vernal ice } \\
66 . \text { Где совет, тут и свет, где любовь, там и Бог / } \\
\text { Where there is advice, there is light, where there is } \\
\text { love, there is God }\end{array}$ & 18 & 6,7 \\
\hline $\begin{array}{l}\text { (По)любить / } \\
\text { love, fall in love }\end{array}$ & $\begin{array}{l}\text { 67. Чужого мужа полюбить - себя погубить / } \\
\text { To love someone else's husband is to ruin yourself } \\
68 . \text { Чужую жену полюбить - свою погубить / } \\
\text { Тo love someone else's wife - to destroy yours } \\
69 \text { (a). Муж жену здоровую любит, а брат сестру } \\
\text { богатую / A husband loves a healthy wife, and } \\
\text { a brother loves a rich sister }\end{array}$ & 13 & 4,8 \\
\hline $\begin{array}{l}\text { Дочь / } \\
\text { daughter }\end{array}$ & $\begin{array}{l}69 \text { (b). Дочь - чужое сокровище / Daughter is } \\
\text { someone else's treasure } \\
70 \text {. Дочь отцу с матерью не корысть: пои-корми, } \\
\text { да и в люди отдай / Father and mother do not have } \\
\text { a daughter for self-interest: feed, breed, and give } \\
\text { her to people } \\
71 . \text { Дочь - матери помощница / A daughter is } \\
\text { mother's helper }\end{array}$ & 12 & 4,4 \\
\hline
\end{tabular}


Continuation of the table 2 / Продолжение табл. 2

\begin{tabular}{|c|c|c|c|}
\hline Key lexeme & Examples & $\begin{array}{l}\text { Number } \\
\text { of uses }\end{array}$ & $\begin{array}{l}\text { Percentage } \\
\text { of uses }\end{array}$ \\
\hline $\begin{array}{l}(\text { По)женить (ся) / } \\
\text { marry, get } \\
\text { married }\end{array}$ & $\begin{array}{l}\text { 72. Если любишь, то женись, а не любишь - } \\
\text { отвяжись / If you love, then marry, if you don't - } \\
\text { let go } \\
\text { 73. Жениться - не напасть, да как бы женатому } \\
\text { не пропасть / To marry is not a big deal, but how } \\
\text { not to get lost }\end{array}$ & 11 & 4,1 \\
\hline $\begin{array}{l}\text { Брат, } \\
\text { братство / } \\
\text { brother, } \\
\text { brotherhood }\end{array}$ & $\begin{array}{l}\text { 74. Брат братом, сват сватом, а денежки не } \\
\text { родня / Brother is brother, in-laws are in-laws, but } \\
\text { money is separately } \\
\text { 75. Брат за брата не ответчик / One brother is not } \\
\text { responsible for another } \\
76 . \text { Доброе братство лучше богатства / Good } \\
\text { brotherhood is better than wealth }\end{array}$ & 10 & 3,7 \\
\hline $\begin{array}{l}\text { Зять / } \\
\text { son-in-law }\end{array}$ & $\begin{array}{l}\text { 77. Зять любит взять, да не любит отдать / } \\
\text { The son-in-law likes to take, but he does not like to give } \\
\text { 78. Зять на двор - пирог на стол / Son-in-law } \\
\text { comes - lay the table }\end{array}$ & 10 & 3,7 \\
\hline $\begin{array}{l}\text { Свекровь / } \\
\text { mother-in-law }\end{array}$ & $\begin{array}{l}\text { 79. У лихой свекрови и на затылке глаза / } \\
\text { The dashing mother-in-law has eyes on the back of } \\
\text { the head } \\
\text { 80. Сноха веселится, свекровь злится / } \\
\text { The daughter-in-law is having fun, the mother-in- } \\
\text { law is angry }\end{array}$ & 10 & 3,7 \\
\hline $\begin{array}{l}\text { Теща / } \\
\text { mother-in-law }\end{array}$ & $\begin{array}{l}\text { 81. Теща в дом - дом кверху дном / } \\
\text { Mother-in-law in the house - house upside down } \\
\text { 82. У тещи для зятя и ступа доится / At the mother- } \\
\text { in-law's even pounder is milked for the son-in-law }\end{array}$ & 9 & 3,3 \\
\hline $\begin{array}{l}\text { Милый, } \\
\text { любимый / } \\
\text { sweetheart, } \\
\text { beloved }\end{array}$ & $\begin{array}{l}\text { 83. С немилым жить - только маяться / To live } \\
\text { with not beloved - only toil } \\
\text { 84. Чужой муж мил, да не жить мне с ним, а свой } \\
\text { постыл - волочиться с ним / Someone else's } \\
\text { husband is sweet, but I can't live with him, but my } \\
\text { own is hateful - to drag with him }\end{array}$ & 8 & 3 \\
\hline $\begin{array}{l}\text { Сноха, } \\
\text { невестка / } \\
\text { daughter-in-law }\end{array}$ & $\begin{array}{l}\text { 85. Блудливая свекровь и честной снохе } \\
\text { не верит / The lascivious mother-in-law does not } \\
\text { believe the honest daughter-in-law } \\
\text { 86. Рано невестка встала, да мало напряла / } \\
\text { The daughter-in-law got up early, but she strained } \\
\text { very little }\end{array}$ & 8 & 3 \\
\hline $\begin{array}{l}\text { Дом / } \\
\text { house }\end{array}$ & $\begin{array}{l}\text { 87. Сын глядит в дом, а дочь глядит вон / The son } \\
\text { looks into the house, and the daughter looks out }\end{array}$ & 8 & 3 \\
\hline $\begin{array}{l}\text { Постылый, } \\
\text { нелюбимый, } \\
\text { немилый / } \\
\text { hateful, } \\
\text { unloved, } \\
\text { unwelcoming }\end{array}$ & $\begin{array}{l}\text { 88. Любовь остыла, и жена постыла / Love has } \\
\text { grown cold and the wife has grown cold } \\
\text { 89. Нелюбимое дитя больше ест / Unloved child } \\
\text { eats more } \\
\text { 90. Немилый поперек кровати ложится / } \\
\text { The unwelcoming one lies across the bed }\end{array}$ & 7 & 2,6 \\
\hline $\begin{array}{l}\text { Невеста / } \\
\text { fiancé }\end{array}$ & $\begin{array}{l}\text { 91. Хороша невеста Аннушка, хвалит мать } \\
\text { и бабушка / Mother and grandmother praise a good } \\
\text { fiancé (Annushka) }\end{array}$ & 6 & 2,2 \\
\hline $\begin{array}{l}\text { Женатый / } \\
\text { married }\end{array}$ & $\begin{array}{l}\text { 92. Постой, холостой, дай сказать женатому / } \\
\text { Wait, a single, let the married man tell }\end{array}$ & 5 & 1,9 \\
\hline
\end{tabular}


Continuation of the table 2 / Продолжение табл. 2

\begin{tabular}{|c|c|c|c|}
\hline Key lexeme & Examples & $\begin{array}{c}\text { Number } \\
\text { of uses }\end{array}$ & $\begin{array}{c}\text { Percentage } \\
\text { of uses }\end{array}$ \\
\hline $\begin{array}{l}\text { Родить / } \\
\text { Give birth }\end{array}$ & $\begin{array}{l}\text { 93. Не та мать, что родила, а та, что выходила / } \\
\text { Not the mother who gave birth, but the one who } \\
\text { brought up } \\
\text { 94. Не тот отец-мать, что родил, а тот, кто } \\
\text { воспитал и добру научил / Not the father-mother } \\
\text { who gave birth, but the one who brought up and } \\
\text { taught good }\end{array}$ & 5 & 1,9 \\
\hline $\begin{array}{l}\text { Выбирать, } \\
\text { брать / } \\
\text { choose, take }\end{array}$ & $\begin{array}{l}\text { 95. Жену выбирай не глазами, а ушами / Choose } \\
\text { your wife not with your eyes, but with your ears } \\
\text { 96. Первую дочь бери по отцу, по матери, } \\
\text { a вторую - по сестре / Take the first daughter by } \\
\text { her father, by her mother, and the second by her } \\
\text { sister }\end{array}$ & 5 & 1,9 \\
\hline $\begin{array}{l}\text { Семья / } \\
\text { family }\end{array}$ & $\begin{array}{l}\text { 97. В родной семье и каша гуще / In the family } \\
\text { even porridge is thicker } \\
\text { 98. Вся семья вместе, так и душа на месте / } \\
\text { The whole family is together, and the soul is in peace } \\
\text { 99. Семья без детей - что часы без гирьки / } \\
\text { A family without children is like a clock without a weight }\end{array}$ & 4 & 1,5 \\
\hline $\begin{array}{l}\text { Золовка, } \\
\text { золовушка / } \\
\text { sister-in-law }\end{array}$ & $\begin{array}{l}\text { 100. Золовка - змеиная головка / Sister-in-law is } \\
\text { like a snake head } \\
\text { 101. Лучше деверя четыре, чем золовушка одна / } \\
\text { Better four brothers-in-law than one sister-in-law }\end{array}$ & 4 & 1,5 \\
\hline $\begin{array}{l}\text { Сват, сватья / } \\
\text { matchmaker }\end{array}$ & $\begin{array}{l}\text { 102. Зять да сват - у тещи первые гости / Son-in- } \\
\text { law and matchmaker are mother's-in-law first guests } \\
\text { 103. Знают сватью и в старом платье / They } \\
\text { recognize a matchmaker even in an old dress }\end{array}$ & 4 & 1,5 \\
\hline $\begin{array}{l}\text { Сирота, } \\
\text { сиротство / } \\
\text { orphan, } \\
\text { orphanhood }\end{array}$ & $\begin{array}{l}\text { 104. Без отца дитя - полсироты, без матери } \\
\text { дитя - полная сирота / Without a father, a child is } \\
\text { half an orphan, without a mother, a child is a } \\
\text { complete orphan } \\
105 . \text { В сиротстве жить - только слезы лить / } \\
\text { To live in orphanhood is only to shed tears }\end{array}$ & 4 & 1,5 \\
\hline $\begin{array}{l}\text { Браниться / } \\
\text { scold }\end{array}$ & $\begin{array}{l}\text { 106. Молодые бранятся - тешатся, старики } \\
\text { бранятся - бесятся /Young scold - they amuse, } \\
\text { old people scold - they rage } \\
\text { 107. Муж с женой бранятся, да под одно одеяло } \\
\text { ложатся / Husband and wife scold, but they lie } \\
\text { under blanket together }\end{array}$ & 4 & 1,5 \\
\hline $\begin{array}{l}\text { Дед, дедушка / } \\
\text { grandfather, } \\
\text { grandpa }\end{array}$ & $\begin{array}{l}\text { 108. Дедушка и не ведает, где внучек обедает / } \\
\text { Grandfather doesn't know where his grandson dines }\end{array}$ & 4 & 1,5 \\
\hline $\begin{array}{l}\text { Лад / } \\
\text { concord }\end{array}$ & $\begin{array}{l}\text { 109. Где мир да лад, там и благодать Божья / } \\
\text { Where there is peace and harmony, there is the } \\
\text { grace of God }\end{array}$ & 3 & 1,1 \\
\hline $\begin{array}{l}\text { Родители / } \\
\text { parents }\end{array}$ & $\begin{array}{l}\text { 110. Родители берегут дочь до венца, а муж } \\
\text { жену - до конца / Parents protect their daughter } \\
\text { until the marriage, and the husband protects his wife } \\
\text { until the end }\end{array}$ & 3 & 1,1 \\
\hline $\begin{array}{l}\text { Совет / } \\
\text { affection, } \\
\text { concord }\end{array}$ & $\begin{array}{l}\text { 111. Где любовь да совет, там и рай, там и свет; } \\
\text { a ссоры да споры, там только лишь вздоры / } \\
\text { Where there is love and concord, there is paradise, } \\
\text { there is light; where there are disputes, there are } \\
\text { only quarrels }\end{array}$ & 3 & 1,1 \\
\hline
\end{tabular}


The end of the table 2 / Окончание табл. 2

\begin{tabular}{|c|c|c|c|}
\hline Key lexeme & Examples & $\begin{array}{c}\text { Number } \\
\text { of uses }\end{array}$ & $\begin{array}{l}\text { Percentage } \\
\text { of uses }\end{array}$ \\
\hline $\begin{array}{l}\text { Родня / } \\
\text { relatives }\end{array}$ & $\begin{array}{l}\text { 112. Едет женина родня - открывай ворота, едет } \\
\text { мужнина родня - запирай двери / Wife's relatives } \\
\text { are going - open the gates, husband's relatives are } \\
\text { going - lock the doors }\end{array}$ & 3 & 1,1 \\
\hline $\begin{array}{l}\text { Холостой / } \\
\text { single }\end{array}$ & $\begin{array}{l}\text { 113. Холостого сватом не посылают / Single } \\
\text { matchmakers are never sent for }\end{array}$ & 3 & 1,1 \\
\hline $\begin{array}{l}\text { Сестра / } \\
\text { sister }\end{array}$ & $\begin{array}{l}\text { 114. Брат сестру любит богатую, а тещу } \\
\text { тороватою / Brother loves his sister rich, and } \\
\text { mother-in-law - tough }\end{array}$ & 3 & 1,1 \\
\hline $\begin{array}{l}\text { (Вс)кормить / } \\
\text { feed }\end{array}$ & $\begin{array}{l}\text { 115. Родителей кормить - что старые долги } \\
\text { платить / Parents to feed - old debts to pay }\end{array}$ & 3 & 1,1 \\
\hline $\begin{array}{l}\text { Внук }(и) / \\
\text { grandchildren }\end{array}$ & $\begin{array}{l}\text { 116. Что было - видели деды, что будет - увидят } \\
\text { внуки / Grandfathers see the past, grandchildren } \\
\text { see the future }\end{array}$ & 2 & 0,7 \\
\hline $\begin{array}{l}\text { Вдова, } \\
\text { вдовушка / } \\
\text { widow }\end{array}$ & $\begin{array}{l}\text { 117. На вдове жениться, как старые штаны } \\
\text { надевать: не вошь, так гнида укусит / Тo marry a } \\
\text { widow, as to put on old pants: not a louse, so the nit } \\
\text { will bite } \\
118 . \text { У вдовушки обычай не девичий / The widow's } \\
\text { custom is not girlish }\end{array}$ & 2 & 0,7 \\
\hline $\begin{array}{l}\text { Замужество / } \\
\text { marriage }\end{array}$ & $\begin{array}{l}\text { 119. Хвали дочь в замужестве / Praise your } \\
\text { daughter in marriage } \\
\text { 120. Девушка красна до замужества / Girl is } \\
\text { beautiful before marriage }\end{array}$ & 2 & 0,7 \\
\hline $\begin{array}{l}\text { Женитьба } \\
\text { marriage }\end{array}$ & $\begin{array}{l}\text { 121. До женитьбы все заживет / Everything will } \\
\text { heal before marriage } \\
\text { 122. Молодому женитьба - рано, a старому - } \\
\text { поздно / It's early for a young man to get married, } \\
\text { but for an old man it's too late }\end{array}$ & 2 & 0,7 \\
\hline $\begin{array}{l}\text { Воспитать / } \\
\text { bring up }\end{array}$ & $\begin{array}{l}\text { 123. Не тот отец-мать, что родил, а тот, кто } \\
\text { воспитал и добру научил / Not the father or mother } \\
\text { who gave birth, but the ones who brought up and } \\
\text { taught good } \\
\text { 124. Одними ласками не воспитаешь / } \\
\text { One cannot brought up with caresses only }\end{array}$ & 2 & 0,7 \\
\hline
\end{tabular}

In the material of Russian proverbs, the lexeme wife is also in first place in terms of the number of uses, and, in contrast to French proverbs, which differ mainly in a negative assessment, this unit is used with various evaluative adjectives. A wife can be either плохая / bad, злая / evil, худая / thin, or хорошая / good, добрая / kind, красивая / beautiful (examples 45, 47):

125. Зльх всех злее злая жена / The wicked of all wicked, is the wicked wife;

126. Добрая жена - веселье, ахудая - злое зелье / A good wife is fun, and a thin one is an evil potion.

As you can see from the examples, the opposition плохая / хорошая жена / bad / good wife can be found within the same unit and expresses a pronounced semantic condensation in Russian proverbs.

Women's shortcomings, advantages and, in general, character traits are most clearly reflected in the heading Man and Woman, where female representatives are 
illustrated by the lexemes баба / old woman, wife (6 uses - 2.2\%), бабий / women's — vulg. (11-4.1\%), девушка / young girl $(6-2.2 \%)$, девка / lass $(2-0.7 \%)$, female $(2-0.7 \%)$ :

127. У бабы волос долог, да ум короток / A woman's hair is long, but her mind is short;

128. Бабий язык - чёртово помело / The woman's tongue is a devilish mob;

129. Приехала баба из города, привезла вестей с три короба / A woman came from the city, talked our ears off;

130. Бабья дорога — от печи до порога / Woman's road — from the stove to the threshold;

131. Девка красива, да прясть ленива / The girl is beautiful but lazy;

132. Женский ум лучше всяких (многих) дум / The female mind is better than any (many) thoughts.

Apart from the latter, negative assessment prevails in these proverbs, which also reflects a critical attitude towards a woman and her dependence on a man and the need to obey him (example 48 - cf. French example 23; 130). This semantic condensation is neutralized by the content of other units expressing a certain balance of the roles and responsibilities of husband and wife, and even equality (example 49), as well as:

133. Жена мужу не прислуга, а подруга / The wife is not a servant to her husband, but a friend;

134. Муж - голова, жена - шея: куда захочет, туда и повернет / The husband is the head, the wife is the neck: wherever he wants, he will turn there;

135. Муж - за чарку, а жена - за палку / The husband goes for a glass, and the wife - for a stick;

136. Муж - в поле пахать, а жена - руками махать / The husband is to plow in the field, and the wife is to wave her hands;

137. Муж да жена - одна сатана / Husband and wife are one Satan.

The advantage of a married person over a single person is expressed (examples 65, 92), which is not reflected in the French material.

We shall note that, unlike French proverbs, Russian proverbs have enough examples of the use of the lexeme myx / husband (32 uses - 11.9\%), who can also be not only хорошим (добрым, умным) / good (kind, smart), but also плохим / bad (examples 53, 54, 55 ). In addition, it is emphasized that a wife needs a husband, and a husband needs a wife:

138. Муж без жены - что гусь без воды / A husband without a wife is like a goose without water;

139. Без жены как без шапки / Being without a wife is as being without a hat;

140. Жена без мужа - всего хуже / A woman without a husband is the worst.

Russian proverbial material, like French, contains tips on how to choose a wife (examples 95, 96, 117).

Besides, a feature of Russian material is the presence of a number of proverbs about other people's wives and husbands and relationships with them (examples $67,68,84)$. 
The lexeme мужчина / man was not found in our material, and the unit мyжик/мужичок / man — vulg. has only three uses in the proverbs of the heading Мужчина и женщина / Man and woman:

141. Мужика не иуба греет, а топор / The man is not warmed by a fur coat, but an ax.

As in French material, the role of children and parents is very important. In the proverbs of this theme, in general, similar semantic condensations were found: the power of maternal love (56-58), the importance of parenting (examples 56$58,62-64,93,94,104,105,123)$, the presence of children in the family $(51,59$, $60,99)$, the similarity of parents and children and their difference $(52,62-64)$. Thus, our material largely confirms the idea that "paremic condensations do not have a national connection - they are international. So, the generalized idea "A child is like a parent" is presented by the PU of various languages" [9. P. 60]. However, the theme of the ingratitude of children was not directly reflected in the material (with the exception of example 115, in which the duty to feed the parents is regarded as an onerous duty), which is possibly related to the importance of the tradition of honouring parents:

142. Живы родители — почитай, померли — поминай / Alive parents honor them, died - remember;

143. Дети родителям не судьи / Children are not judges to parents.

A separate role is assigned to the upbringing of children, including in severity - examples 123, 124, as well as:

144. Матерни побои не больны / Mothers' beatings are not painful;

145. Детей наказывай стылом, а не кнутом / Punish children with shame, not a whip;

146. Нелюбимого сына - лозою, любимого - жезлом / The unloved son - with the vine, the beloved — with the rod.

There are 2 times more proverbs about sons $(24$ units - 8.9\%) than about daughters $(12$ units - 4.4\%). This ratio is explained by the very content of the proverbs, revealing that parents pin great hopes on sons (example 59) than on daughters, who are considered someone else's treasure (example 69 (b)), but at the same time a mother's helper (example 71). Daughters, however, must be protected until marriage (example 110) and praised in marriage (example 119), since the creation of a worthy family by her is a priority. In general, representatives of the Russian linguistic culture are characterized by the fact that caring for children continues throughout their lives and that there are even more worries about adult children than about little ones (example 50).

A distinctive feature of Russian proverbial material in comparison with French is the mention of a large number of relatives, diversity and contradictions between close and distant relatives: husband and wife, brother and sister, mother-in-law and son-in-law, daughter-in-law and mother-in-law, etc., many of which are presented ironically (examples 74-82, 85-86, 100-103, 106-108). Thus, key lexemes in Russian proverbs denote the entire structure of family relations: close and distant kinship. Let us clarify that "close relationship includes the concepts of 
blood relationship (ancestors, mother, father, brother, sister, descendants) and relationship through marriage (relationship to a spouse); the distant one presupposes family relations in the next tribe (uncle, aunt, nephews) and subsequent relations with the spouse's generation (ancestors, mother-in-law, father-in-law)" [1. P. 78-79]. This fact once again confirms that the closeness of relations between people, characteristic of Russians - representatives of collectivist culture [for more details see: 25], allows us to perceive the family as a union, a single whole. Nevertheless, the contradictions between relatives are very aptly expressed in the following proverb:

147. Хороша родня, когда она далеко живет / Relatives are good when they live far away.

Let us note that the French material mainly reflects consanguinity and marriage. The mother-in-law is mentioned once in the proverb of Guadeloupe (example 20), which can be explained by a significantly greater degree of collectivism in the linguistic consciousness of the Francophones of this country and the recognition of a large family as a norm than in France. Most likely, the same fact explains that family ties in Russian material more often than in French are expressed by the presence of several units within one proverb (examples 49, 52, 59, 61, 69 (a and b), 70, 71, 74, 80, 82, 85, 87, 91, 96, 101, 102, 104, 107-109, 112, $114,116,133-138,140,143)$, that is, they differ in a greater degree of concentration of thematic key lexemes in the analyzed material.

As in French (examples 1, 22, 23, 29), there are zoomorphisms in Russian proverbs about the family - examples $54,55,100$, as well as:

148. Будь жена хоть коза, только б золотье рога / Be a wife, even a goat, only golden horns;

149. Кошка да баба в избе, мужик да собака на дворе / A cat and a woman in the hut, a man and a dog in the yard.

Zoometaphors associated with the image of a snake (уж / grass snake, змея / snake) serve in Russian proverbs to convey the bad character of women and men, a cat symbolizes comfort in the house, and a dog - loyalty and protection. A vivid, ironic and very witty metaphorical image of the queen pig (example 54) is achieved by combining not very compatible portraits of one of the unsightly domestic animals raised mainly for slaughter and the queen. At the same time, an important role belongs to the diminutive-derogatory suffix $-\kappa$ and the use of господинка in the feminine gender. It is important to note the frequency of the use of this and other diminutive evaluative suffixes in Russian proverbs in general and proverbs about the family, in particular (examples 50, 52, 54, 100, 101, 108) in lexemes Аннушка / Annushka, золовушка / sister-in-law, внучек / grandson, детки / children, бедки / troubles, where they allow you to express irony and, at the same time, soften the negative assessment. Due to such derivational formants with a subjectiveevaluative meaning, the expression of the proverbial sign increases [26. P. 100]. In the French proverbs of this theme, no such means of expressing evaluation have been identified.

In contrast to the French material, in Russian there were 18 cases $(6.7 \%)$ of the use of the lexeme любовь / love (4.8\%), (не / по)любить / (not) love, fall in love 
(examples 65-69 (a), 72, 77, 111, 114). The theme of love is also expressed by the lexemes мильй / sweetheart, немильй, постылый, нелюбимый / unwelcoming, hateful, unloved (examples 83-84, 88-90, 141). Thus, this topic is expressed in 46 units (17\% of the total number of proverbs), which, of course, allows us to single out love as a value adjacent to the family.

Such an emotional and sensory orientation of Russian proverbs, according to our assumption, may be associated with the fact that the Russian language largely tends towards an impressionistic orientation. In this case, we mean one of the two opposite psychological tendencies identified by S. Bally and which are manifested both in the vocabulary and in the syntax of languages: "impressionistic, which is characterized by the reflection of phenomena from the point of view of their perception, and analytical, focused on the rationalistic representation of the relationship between cause and effect" [Cit. after: 27. P. 39]. According to this point of view, the emotional state of a person, the feelings and emotions he or she experiences, find a detailed representation in the Russian material.

Themes not found in the French material are orphanhood (examples 104$105)$ and widowhood (117-118). The semantic condensation of these proverbs is the unenviable fate of widows and orphans.

In Russian proverbs about family and family life, there are not so many household items as in French ones. Perhaps this pragmatic orientation of metaphorical images can be explained by the fact that the French language belongs to the above-mentioned analytical type. In any case, among other factors, the realities of everyday culture, "imprinted in memory and images of consciousness, serve as a source of metaphors, painting them in nationally specific colors" [28. P. 913]. In Russian material, we found such lexemes associated with the house as изба / hut, двор / yard (examples 78, 148), печь / stove (130), nорог / threshold (130) as a symbol of the border of a house, а постель / bed and одеяло / blanket (examples 90,107), which act as a symbol of close relations between spouses, $л а$ вочка / bench:

150. Учи дитя, пока поперек лавочки лежит, а как вдоль лавочки ляжет, тогда поздно учить / Teach the child while he lies across the bench, and as he lies along the bench, then it's too late to teach.

There are no mentions of cuisine in our card index of Russian proverbs, but there are lexemes denoting traditional Russian food: $щ и$ / cabbage soup (example 45), мед / honey (46) as a symbol of sweetness and pleasure, пирог / pie (78), каша / porridge (97), which is thicker, more nourishing.

The analysis of Russian proverbs about the family made it possible to reveal, in addition to love, which was mentioned above, the following contiguous values and value dyads, in most cases coinciding with the contiguous values reflected in the French material: happiness - unhappiness - this dyad is expressed mainly through the common meaning of proverbs using different lexemes $(48,51,57,66$, $67,68,73,83,84,88,97,98,105,109,111)$; good-evil $(45,47,50,80,94,100$, $123,125,126)$; work - laziness $(62,63,86,131,136,136,141)$; faith, religion (46, 66, 109, 111, 128, 137); intellect - stupidity (examples 53, 64, 127, 132, 148); 
wealth - poverty $(74,76,114,147)$; peace - quarrels $(66,106,107,109,111)$; health (69 (a)); food (45, 46, 78, 97); beauty $(120,121)$; friendship (133). In Russian material, duality (mentioning both values and anti-values) is more pronounced and can be observed within one unit, including with the help of antithesis (examples 47, $50,53,72,77,80,84,106,111,112,126,142,146)$.

Separately, we would like to emphasize the following fact. In French material, the percentage of the use of verb lexemes associated with family and various situations of family life $(15.6 \%)$ is less than in Russian (24\%), where they are even more diverse: жениться / marry, свататься / wоo, кумиться / become godparents, любить / love, браниться / scold, ложиться и валиться спать (под одно одеяло) / going to bed and fall asleep (under one blanket), выбирать / choose, брать (в жень) / take (as a wife), родить / give birth, воспитьвать bring up, наказывать / punish, учить / teach, хвалить / praise, бить (как жену, так и детей) / beat (both wife and children), мести / sweep, nоuть / give drink, кормuть / feed. In both languages are used verbs épouser and se marier / get married, prendre / take (as a wife), nourrir / feed, balayer / sweep, only in French material there are bercer / lull, déménager / move the house, laver / wash, garder / take care of (home), bouillir / boil, cuire / cook, stew. Almost all these verbs, in contrast to the Russian ones, were rarely encountered in proverbs, so we did not include them in the table.

This feature may be associated with the predicativeness of the Russian language [see. See also: 26. P. 101] and the nominative nature of French [28]. In both languages, verbs are used in different tenses of the indicative mood, as well as the imperative for expressing persistent advice or warning. In the French material, for the same purposes is used the construction $\mathrm{il}$ faut / it is needed (examples 9, 16, 32).

\section{Conclusion}

The analysis of French and Russian proverbs of the thematic group family, carried out on the material of two French and two Russian dictionaries of proverbs, showed a significant number of coincidences of proverbial condensations. The differences mainly lie in the fact that the French material (114 proverbs common to the two dictionaries) showed a more individualistic and pragmatic-everyday orientation, and Russian (270 common units found in two dictionaries) was more collective-oriented, in this the case to a family, and an emotional and sensory set. Russian proverbs are also distinguished by a greater degree of concentration of thematic key lexemes, among which verbs are used more often than in French material.

The revealed contiguous values and anti-values also showed a significant degree of similarity in the perception of the universal value of family. In Russian material, duality is expressed to a greater extent, where value and anti-value often find expression even within the same proverb.

Thus, the specificity of semantic condensations and value perception of the family in proverbial material is represented with the use of units of different linguistic levels. 
The peculiarities of their functioning are explained by the combination of typological features of the compared languages, which, in turn, are closely related to the uniqueness of the worldview and thinking of individual ethnic groups.

\section{References}

1. Shimko, E.A. (2019). Explication of cultural values in lexico-phraseological systems of related languages [dissertation]. Mytischi. (In Russ.).

2. Bréchon, Pierre, Frédéric Gonthier \& Sandrine Astor (dir.). (2019). La France des valeurs. Quarante ans d'évolutions. Grenoble: Presses universitaires de Grenoble.

3. Sergeeva, A.V. Russians: behavioral stereotypes, traditions, mentality. URL: https://culture.wikireading.ru/38226 (accessed: 25.06.2021). (In Russ.).

4. Krasina, E.A. (2020). Review on the Book: Kryukova O.P. Verbal-intellectual Activity in linguistic theory and teaching practice (Experimental study of cognitive structures of language acquisition in English and Russian): [Electronic resource]: monography. Text electronic data (3.3 Mb). Moscow: IIU MGOU, 2019. CD-ROM opt. disk. Systemic requirements: Intel Pentium or the analogues, $1 \mathrm{GGH} ; 512 \mathrm{Mb}$ short term memory; CD-ROM drive; Microsoft Windows XP SL 2 or the next ones; Adobe Reader 7.0 (or the analogues to read pdf files) // RUDN Journal of Language Studies, Semiotics and Semantics, 11(3), 596-603. doi: 10.22363/2313-2299-2020-11-3-596-603.

5. Lomakina, O.V. \& Mokienko, V.M. (2018). Value constants of the Rusin paremiology (compared with the the Ukrainian and Russian languages). Rusin, 4, 303-317. (In Russ.).

6. Karasik, V.I. (2015). Linguocultural Values in Discourse. Foreign Languages in Tertiary Education, 1, 25-35. (In Russ.).

7. Semenenko, N.N. (2011). Russian paremias: functions, semantics, pragmatics: Monograph. Stary Oskol: ROSA Publishing House. (In Russ.).

8. Lomakina, O.V. (2021). Conceptualization of general human values in addresses (On the material of Russian, Uzbek and Tajik Languages). Cognitive Studies of Language, 3(46), 172 175. (In Russ.).

9. Seliverstova, E.I. (2014). National Identity of Proverbs in the Context of Multilingual Dictionaries. Journal of Historical, Philological and Cultural Studies, 3(45), 58 - 61. (In Russ.).

10. Bredis, M.A. (2019). Man and Money: Essays on Russian and other Proverbs. SaintPetersbourg: Peterburgskoe Vostokovedenie. (In Russ.).

11. Lomakina, O.V. (2021). Concepts of god and faith in Uzbek and Tajik proverbs in terms of culture and language transfer theory. European Journal of Science and Theology, 17(2), 125-135.

12. URL: https://translate.academic.ru/qui $\% 20 \mathrm{femme} \% 20 \mathrm{a} \% 2 \mathrm{C} \% 20 \mathrm{guerre} \% 20 \mathrm{a} / \mathrm{fr} / \mathrm{ru} / \#$ (accessed: 25.06.2021).

13. Montreynaud F., Pierron A., Suzzoni F. (2010). Dictionnaire de proverbes et dictons. Paris: Le Robert.

14. Nelyubova, N.Yu. (2019). The family as a universal value in the French and Russian proverbial picture of the world. Philological Sciences-Scientific Essays of Higher Education, 6, 50-59. (In Russ.).

15. Les proverbs. URL: http://www.linternaute.fr/proverbe/theme/ (accessed: 26.06.2021).

16. Nelyubova, N.Yu., Syomina P.S. \& Ershov, V.I. (2018). Concepts «Woman», «Man», «Love» in French proverbs (based on the French language of France and Belgium). RUDN Journal of Language Studies, Semiotics and Semantics, 9(4), 926-943. (In Russ.).

17. Lomakina, O.V. (2018). Phraseology in the text: functioning and idiostyle [monograph]. V.M. Mokienko (Ed.). Moscow: RUDN. (In Russ.).

18. Nelyubova, N.U., Syomina, P.S. \& Kazlauskiene, V.I. (2020). Gourmandise in the hierarchy of values: A case study of French and Belgian proverbs and sayings. Russian Journal of Linguistics, 24(4), 969-990. DOI: 10.22363/2687-0088-2020-24-4-969-990 (In Russ.). 
19. Bréchon, P. (2016). Quelles sont les valeurs des Français? Sciences Humaines. Grands Dossiers, 44.

20. Novospasskaya, N.V., Raadraniriana, A.M. \& Lazareva, O.V. (2019). Image of a Woman in Russian, French, Spanish and Malagasian Linguocultures on the Material of Paremia. RUDN Journal of Language Studies, Semiotics and Semantics, 10(2), 301-322. DOI: 10.22363/23132299-2019-10-2-301-322. (In Russ.).

21. Nelyubova, N.Yu. (2019). Presentation of Values in the Proverbs of French-speaking Countries (based on proverbs of Martinique). University bulletin (Russian-Tajik (slavonic) university), 1(65), 198-208. (In Russ.).

22. Nelubova, N.Yu. (2019). Representation of Ethno-cultural Values in the Proverbs of Frenchspeaking Countries. RUDN Journal of Language Studies, Semiotics and Semantics, 10(2), 323-335. DOI: (In Russ.).

23. Zimin, V.I. (2020). Dictionary-thesaurus of Russian proverbs, sayings and apt expressions. Moscow, APS. (In Russ.).

24. Mokienko, V.M. \& Nikitina, T.G. (2011). Folk wisdom. Moscow: Olma Media Groop. (In Russ.).

25. Nelyubova, N. Y., Hiltbrunner, V.I. \& Ershov, V.I. (2019). The Reflection of the Hierarchy of Values in the Proverbial Fund of the Russian and French languages. Russian Journal of Linguistics, 23(1), 223-243. DOI: 10.22363/2312-9182-2019-23-1-223-243. (In Russ.).

26. Lomakina, O.V. (2021). The Studying of the Proverbs in the Value Paradigm: the Methodology of Research and the Criteria for Estimating Value. Scientific Notes of V.I. Vernadsky Crimean Federal University. Philological sciences, 7(73)-1, 97-107. (In Russ.).

27. Kozlova, L.A. (2019). Comparative typology of English and Russian languages. Barnaul: Altai University publ. (In Russ.).

28. Kozlova, L.A. (2020). Metaphor as the refection of culture determined cognition. Russian Journal of Linguistics, 24(4), 899—925. DOI: 10.22363/2687-0088-2020-24-4-899-925. (In Russ.).

\section{Библиографический список}

1. Шимко E.A. Экспликация культурных ценностей в лексико-фразеологических системах родственных языков. дисс. Мытищи, 2019.

2. Bréchon Pierre, Frédéric Gonthier, Sandrine Astor. La France des valeurs. Quarante ans d'évolutions. Grenoble: Presses universitaires de Grenoble, 2019.

3. Сергеева A.B. Русские: стереотипы поведения, традиции, ментальность. М.: Флинта Наука, 2004. [Электронный ресурс] Режим доступа: https://culture.wikireading.ru/38226 (дата обращения: 26.06.2021).

4. Красина Е.А. Рецензия на монографию О.П. Крюковой «Речемыслительная деятельность в лингвистической теории образовательной практике (экспериментальное исследование когнитивной организации лингвистических знаний на материале английского и русского языков) [Электронный ресурс]: монография. - Электронные текстовые данные (3,3 Мб). Москва: ИИУ МГОУ, 2019. // Вестник Российского университета дружбы народов. Серия: Теория языка. Семиотика. Семантика. 2020. Т. 11. № 3. С. 597-604.

5. Ломакина O.B., Мокиенко B.M. Ценностные константы Русинской паремиологии (на фоне украинского и русского языков) // Русин. 2018. № 4. С. 303-317.

6. Карасик В.И. Лингвокультурные ценности в дискурсе // Иностранные языки в высшей школе. 2015. № 1. С. 25-35.

7. Семененко Н.Н. Русские паремии: функции, семантика, прагматика: Монография. Старый Оскол: Изд-во РОСА, 2011.

8. Ломакина О.В. Концептуализация общечеловеческих ценностей в пословицах (на материале русского, узбекского и таджикского языков) // Когнитивные исследования языка. 2021. № 3 (46). С. 172-175.

9. Селиверстова Е.И. Национальная самобытность пословиц в свете данных многоязычных словарей // Проблемы истории, филологии, культуры. 2014. № 3 (45). С. 58-61. 
10. Бредис М.A. Человек и деньги: Очерки о пословицах русских и не только. СПб.: Петербургское Востоковедение, 2019.

11. Lomakina O.V. Concepts of god and faith in Uzbek and Tajik proverbs in terms of culture and language transfer theory // European Journal of Science and Theology. April 2021. Vol. 17. No 2. P. $125-135$.

12. Режим доступа: https://translate.academic.ru/qui\%20femme $\% 20 \mathrm{a} \% 2 \mathrm{C} \% 20$ guerre $\% 20 \mathrm{a} / \mathrm{fr} / \mathrm{ru} / \#$ (дата обращения: 25.06.2021).

13. Montreynaud F., Pierron A., Suzzoni F. Dictionnaire de proverbes et dictons. P.: Le Robert, 2010.

14. Нелюбова Н.Ю. Семья как общечеловеческая ценность во французской и русской пословичной картине мира // Филологические науки. Научные доклады высшей школы. 2019. № 6. C. $50-59$.

15. Les proverbs. Режим доступа: http://www.linternaute.fr/proverbe/theme/ (дата обращения: 26.06.2021).

16. Нелюбова Н.Ю., Сёмина П.С., Ершов В.И. Концепты «Женщина», «Мужчина», «Любовь» во французских пословицах (на материале французского языка Франции и Бельгии) // Вестник Российского университета дружбы народов. Серия: Теория языка. Семиотика. Семантика. 2018. Т. 9. № 4. С. 926-943.

17. Ломакина О.В. Фразеология в тексте: функционирование и идиостиль. М.: РУДН, 2018.

18. Нелюбова Н.Ю., Сёмина П.С., Казлаускене В. Гурманство в иерархии ценностей французов и бельгийцев (на материале пословиц и поговорок) // Russian Journal of Linguistics. 2020. T. 24. No 4. C. 969-990. DOI: 10.22363/2687-0088-2020-24-4-969-990.

19. Bréchon, Pierre. Quelles sont les valeurs des Français? // Sciences Humaines. Grands Dossiers. 2016. № 44 .

20. Новоспасская Н.В., Раадранириана А.М.М., Лазарева О.В. Образ женщины в русской, французской, испанской и малагасийской лингвокультурах на материале паремий // Вестник Российского университета дружбы народов. Серия: Теория языка. Семиотика. Семантика. 2019. Т. 10. № 2. С. $301-322$.

21. Нелюбова Н.Ю. Представление ценностей в пословицах франкоязычных стран (на материале пословиц Мартиники) // Вестник университета (Российско-Таджикский (Славянский) университет). 2019. № 1 (65). С. 198-208.

22. Нелюбова Н.Ю. Отражение этнокультурных ценностей в пословицах франкоязычных стран // Вестник Российского университета дружбы народов. Серия: Теория языка. Семиотика. Семантика. 2019. Т. 10. № 2. С. 323-335.

23. Зимин В.И. Словарь-тезаурус русских пословиц, поговорок и метких выражений. М.: АСТ-ПРЕСС ШКОЛА, 2020.

24. Мокиенко В.М., Никитина Т.Г. Народная мудрость. М.: ОЛМА Медиа Групп, 2011.

25. Нелюбова Н.Ю., Хильтбруннер В.И., Ершов В.И. Отражение иерархии ценностей в пословичном фонде русского и французского языков // Russian Journal of Linguistics. 2019. T. 23. № 1. C. $223-243$.

26. Ломакина О.В. Изучение пословиц в русле ценностной парадигмы: методология исследования и критерии выделения оценочности // Ученые записки Крымского федерального университета имени В. И. Вернадского. Филологические науки. Научный журнал. 2021. T. 7 (73). № 1. С. 97-107.

27. Козлова Л.А. Сравнительная типология английского и русского языков. Барнаул: АлтГПУ, 2019.

28. Козлова Л.А. Метафора как отражение этнокультурной детерминированности когниции // Russian Journal of Linguistics. 2020. T. 24. № 4. C. 899-925. DOI: 10.22363/26870088-2020-24-4-899-925.

Information about the authors:

Natalia Yu. Nelyubova, Ph.D., Associate Professor, Foreign Languages Department, RUDN University, Moscow, Russia.e-mail: nelybova_ny@rudn.ru

Scopus ID: 57208208446; ResearcherID: A-6030-2017; ORCID: 0000-0002-6538-8267 
Natalia M. Dugalich, Ph.D., Associate Professor, Foreign Languages Department, RUDN University, Moscow, Russia; e-mail: dugalich_nm@rudn.ru

Scopus ID: 57194526936; ResearcherID: K-8404-2017; ORCID: 0000-0003-1863-2754

Victor I. Ershov, MGIMO University, English language department, associate professor; e-mail: ershovik@mail.ru

Scopus ID: 57208210236; ORCID: 0000-0003-3765-6954

\section{Сведения об авторах:}

Нелюбова Наталия Юрьевна, кандидат филологических наук, доцент, доцент кафедры иностранных языков филологического факультета ФГАОУ ВО «Российский университет дружбы народов»; e-mail: nelybova_ny@rudn.ru

Scopus ID: 57208208446; ResearcherID: A-6030-2017; ORCID: 0000-0002-6538-8267

Дугалич Наталья Михайловна, кандидат филологических наук, доцент кафедры иностранных языков филологического факультета ФГАОУ ВО «Российский университет дружбы народов»; e-mail: dugalich_nm@rudn.ru

Scopus ID: 57194526936; ResearcherID: K-8404-2017; ORCID: 0000-0003-1863-2754

Ершов Виктор Иванович, кандидат филологических наук, доцент кафедры английского языка, Одинцовский филиал МГИМО; e-mail: ershovik@mail.ru

Scopus ID: 57208210236; ORCID: 0000-0003-3765-6954 